\title{
RETALIATION, CATHARSIS AND THE CRIMINAL PROCESS
}

\author{
John Stannard, Senior Lecturer, School of Law, \\ Queen's University Belfast.
}

The purpose of this article is to examine a problem previously discussed by the present author in the pages of this journal: ${ }^{1}$ namely the part, if any, that the outraged feelings of victims and others should be allowed to play in the penal process. Scarcely a day goes by without the significance of this problem being highlighted in the newspapers, or on the radio and TV. On $11^{\text {th }}$ June 2001, for instance, as this article was being prepared for publication, it was reported that Jon Venables and Robert Thompson, the killers of James Bulger, would soon be released from custody, ${ }^{2}$ while on the very same day, Timothy McVeigh, the Oklahoma bomber, was executed by lethal injection in the United States. ${ }^{3}$ Despite the different fates of the defendants in the one case and in the other, both cases gave rise to a similar reaction from victims and relatives. Thus Denise Fergus, the mother of James Bulger, was reported as saying "Common sense says it is too soon to think about letting them out. So far all they have had is to be wrapped in cotton wool and pampered by social workers .... I want to see them sent to a proper adult institution where they would get it a bit harder." 4 In a similar vein Sue Ashford, a survivor of the Oklahoma bombing, in which 168 people died and hundreds more were injured, declared after witnessing the execution of McVeigh 'I'm ticked off. He didn't suffer at all. They should have done the same thing to him he did to other people." Such sentiments may sound shocking and vindictive, but they seem to be part of the human condition. How should the law react to them?

The problem under discussion can arise in a wide variety of cases, as can be shown by looking at a number of instances occurring over the past decade or so. One is in relation to high-profile disasters involving loss of life, such as the railway accidents at Clapham, Southall, Paddington and Hatfield, the Marchioness sinking and the Hillsborough football ground disaster. Perhaps the most discussed case of this sort in the academic literature was the Herald of Free Enterprise disaster of 1987, in which a crowded ferry capsized in Zeebrugge harbour, causing heavy loss of life. At a subsequent inquiry chaired by Sheen $\mathrm{J}^{6}$ the ferry company was found to be gravely at fault and came under very heavy criticism. Afterwards some of the relatives of the deceased, not content with pursuing an action in tort, sought to have the

\footnotetext{
1 "Punishment and Public Relations" (1999) 50 NILQ 204.

2 Daily Mail, $11^{\text {th }}$ June 2001, page 22.

3 Daily Telegraph, $12^{\text {th }}$ June 2001 , page 1.

4 See note 1.

5 See note 2 .

6 MV Herald of Free Enterprise, Report of the Court No 8074 (Department of Transport, 1987); see generally Crainer, Zeebrugge: Learning from Disaster (London, 1993).
} 
company and its senior management indicted for manslaughter. ${ }^{7}$ The coroner ruled that a company could not be indicted for manslaughter, but this was successfully challenged on judicial review. ${ }^{8}$ A prosecution was subsequently brought, but despite the ruling of Turner $\mathrm{J}$ to the effect that a company could indeed be charged with manslaughter, ${ }^{9}$ it collapsed for lack of evidence of the required degree of fault on the part of the defendants. ${ }^{10}$ This caused great outrage to the aggrieved relatives and attracted very hostile comments in the academic press at the time. "Why", asked one commentator, "are companies which kill in the course of commercial undertakings given such indulgence by the State in being prosecuted, if at all, only for regulatory health and safety offences?"11 "Is it right", said another, "that a company, which has caused avoidable death and injury because of gross negligence spread throughout its organisation, should be considered innocent just because no senior employee is guilty of the offence in his own right?"12 A third was even more blunt, remarking tartly, "Only when faced with the possibility of personal incarceration and company stigma will senior officers alter their priorities."13

Another area in which similar considerations have surfaced is in relation to the passing by the courts of what are seen as unduly lenient sentences. The present right of appeal by the prosecution, as set out in section 36 of the Criminal Justice Act 1988, was instituted following widespread public outrage at supposedly lenient sentences passed in a number of notorious cases, including the Ealing Vicarage rape case, ${ }^{14}$ and there can be no doubt that outrage on the part of victims and the public at large can still have an influence in cases of this sort. Thus in the summer of 1991 Penny McAllister, the wife of an Army captain stationed in Northern Ireland, had her throat slit by Susan Christie, a jealous lover of her husband. Christie was subsequently tried for murder, but in the light of psychiatric evidence this was reduced by the jury to manslaughter on the grounds of diminished responsibility, and the defendant was sentenced to five years' imprisonment. This caused an immense public outcry, which even provoked leaders in the national press. Following an invitation by a local newspaper for members of the public to telephone in with their comments, well over three thousand did

7 Burles, (1991) 141 NLJ 609. The case pushed the hitherto comparatively neglected topic of "corporate manslaughter" to the top of the legal agenda: see especially Wells, Corporations and Criminal Responsibility (Oxford University Press, 1993); "Corporations: Culture, Risk and Criminal Liability" [1993] Crim LR 551; Fisse and Braithwaite, Corporations, Crime and Accountability (Cambridge, 1993); Clarkson, "Kicking Corporate Bodies and Damning their Souls" (1996) 59 MLR 557. Recommendations for reform of the law in this area were put forward by the Law Commission in Consultation Paper No 135 Involuntary Manslaughter (London, HMSO, 1994): see McColgan [1994] Crim LR 547.

$8 R \mathrm{v} H M$ Coroner for East Kent ex parte Spooner (1989) 88 Cr App R 10

$9 R$ v $P \&$ O European Ferries (Dover) Ltd (1991) 93 Cr App R 72.

10 Bergman, "Recklessness in the Boardroom" (1990) 140 NLJ 1496.

11 Slapper, "Crime without Conviction" (1992) 142 NLJ 192

12 Burles, op cit at $\mathrm{n} 7, \mathrm{p} 611$.

13 Bergman, op cit at n 10, p 1501.

14 See 113 HC Official Report (6 ${ }^{\text {th }}$ series), cols 1028-1049; 489 HL Official Report ( $5^{\text {th }}$ series), cols $314-355$. 
so. ${ }^{15}$ Out of 3,440 callers, 3,164 said that they thought the sentence was too lenient. As one reporter commented, "the length of the sentence has indeed struck a raw nerve among the Ulster public". ${ }^{16}$ The sentence was subsequently increased on appeal to nine years. ${ }^{17}$

Then there are cases where death has been caused by bad driving. Such a case was that of Stephen Owen, whose young son had been knocked off his bicycle and killed by a lorry driver who was subsequently convicted of causing death by reckless driving, disqualified from driving and sentenced to eighteen months' imprisonment. Despite his bad record, the driver expressed no remorse for the crime, and on his release from prison even continued to drive in defiance of the court's order. All this was too much for the aggrieved father, who wrote angry letters to the Prime Minister and even the Queen demanding that the sentence be increased. When this proved unsuccessful he obtained a shotgun and tried to kill the impenitent lorry driver, after which he gave himself up to the police. Owen was charged with attempted murder, but was acquitted by the jury despite clearly having no legal defence to the charge. The verdict was subsequently welcomed by a writer in The Times, who said: "If any human impulse can be a candidate for transcendental truth, it is surely the love of a parent for a child . . . . And so, when the jury declared Stephen Owen innocent . . . they were elevating the truth of compassion above the truth of fact." 18 Commenting on this, a writer in the Justice of the Peace expressed some disquiet at the verdict, but said that a sentence of five years' maximum for causing death by reckless driving was scarcely adequate. ${ }^{19}$ He added that the courts might have "a therapeutic duty to appease the retributionary instinct in man until we are ready to discard it". ${ }^{20}$ In the same connection Andy Holyoake, a speaker at the annual conference of the Police Federation, called for the introduction of a special motor manslaughter charge on the lines of that found in the United States, with the words: "Does it make any difference to the victim, if his or her killer was driving dangerously or carelessly, with or without the influence of drink or drugs? Does it make any difference to the victim's relatives to know that they are bereaved because of one offence or another?"21 This approach is reflected in a more recent case in South Africa, in which the driver of a tourist coach lost concentration on a mountain road and put his foot on the accelerator instead of the brake, causing a crash in which 28 people died. Sentencing him to six years in prison, the magistrate commented that the relatives and friends of the victims were "probably crying out for vengeance and justice". ${ }^{22}$ Later on he added: "[T] he degree of your negligence was so great that this cannot be dismissed with a slap on the wrists .... I think that

15 Belfast News Letter, $18^{\text {th }}$ June 1992, p 1.

16 Shane Glynn, op cit, $\mathrm{p} 5$.

17 Attorney-General's Reference (No 2 of 1992) [1993] 3 BNIL 113.

18 Janet Daley, The Times, $26^{\text {th }}$ May 1992.

19 Leslie James, "In Search of Justice: Retribution or Deterrence?" (1992) 156 JPN 488. The sentence was subsequently increased to ten years by the Road Traffic Act 1991.

$20 \mathrm{Ibid}$. In as far as the instinct in question is roused by the harm done rather than the culpability of the offender, it is arguably retaliatory rather than retributionary; see below, $\mathrm{n} 96$.

21 Police magazine, vol XXIV no 10 (June 1992) at $\mathrm{p} 21$.

22 Case cited by Block, "Vengeance or Justice?" (2001) 165 JPN 424. 
a sentence that is too lenient will ignore the demand for vengeance and do an injustice to society both locally and abroad." 23

All of these cases serve to exemplify the feelings of anger and resentment that may arise when a punishment seems to fall short of the harm done by the offender. This is especially so in cases where death has been caused. When a "lenient" sentence is handed down in such cases, or a decision made not to prosecute, relatives of the victims and others feel "insulted"; 24 it is felt that the death "has not been taken seriously". ${ }^{25}$ Though this sort of sentiment is not confined to homicide cases, ${ }^{26}$ it is in this context that most of the controversy seems to arise, it being felt perhaps that the taking of human life is something that needs to be marked with condign punishment irrespective of the degree to which those responsible were to blame. ${ }^{27}$ This sentiment, with its emphasis on the victim and those bereaved by the death rather than on the culpability of the offender and the benefit to society, does not square easily with classical theories of punishment, either of the utilitarian or the desert school. Why, it may be asked, should we inflict punishment simply on the basis that the offender has done harm? Where is the evidence that it will benefit anybody? Where, even, is the indication that it was deserved? ${ }^{28}$

Sentencing judges are caught in a dilemma here. On the one hand, it is easy to argue that retaliatory sentiments of the sort expressed in some of the cases we have just mentioned are primitive throwbacks, unworthy of any influence on modern penal practice. ${ }^{29}$ Yet the court disregards such sentiments at its peril, for two reasons. One is that sentences perceived as excessively lenient may well end up being raised on appeal, as in the case of Susan Christie. The other is that victims and others may be encouraged to exact private vengeance of an even worse sort, as in the case of Stephen Owen. ${ }^{30}$ The purpose of this paper is to highlight some of the factors which have a bearing

23 Ibid at 425.

${ }^{24}$ Compare the refusal of the courts to allow the relatives of those killed in the Hillsborough football ground disaster to recover damages for the pain and suffering undergone by the deceased prior to death: a refusal branded by the relatives as "the final insult": see Unger, "Pain and Anger" (1992) 142 NLJ 394. Unger suggests that relatives should be able to recover damages in memoriam in such cases.

25 See the comment of Sue Bandalli on Wells (1978) 66 Cr App R 271, a case where a husband who had repeatedly used violence on his wife, and had ultimately killed her in a rage, was given the defence of provocation: "I was unprepared for the machinations of a system which so trivialised a woman in the face of masculine affront." (1992) 142 NLJ 213.

26 Thus it was an outcry on lenient rape sentences that led to the passing of section 36 of the Criminal Justice Act 1988: see above at nn 14-17.

27 Thus see the comments of Andy Holyoake, above at n 21.

28 Some of the commentators cited above are obviously sensitive to this criticism. Thus James ( op cit at n 19) declares that he cannot afford the "luxury" of retributive $[$ sic] sentiments. In a similar vein Bergman argues that advocates of corporate manslaughter convictions are concerned not with revenge but with "accountability and deterrence": (1990) 141 NLJ 1496 at 1501. But accountability is already provided for by the law of tort, and the effectiveness of deterrence in this type of case is asserted rather than demonstrated.

29 See the discussion of the James Bulger case, below at nn 85-93.

30 As we shall see, one of the earliest functions of criminal law was to discourage the use of private vengeance by the imposition of public sanctions: below, nn 42-48. 
on this dilemma, and to discuss the extent to which vengeance and outrage have a part to play in modern sentencing practice. Though as we have seen the issue can arise in relation to a number of offences, most of our discussion will revolve around homicide, as it is this that gives rise to the dilemma in its most acute form.

\section{Retaliation And Criminal Justice}

Charles Kingsley's immortal children's classic The Water Babies features two contrasting characters: the kindly Mrs DOASYOUWOULDBEDONEBY and the altogether less benevolent Mrs BEDONEBYASYOUDID. Whereas DOASYOUWOULDBEDONEBY symbolises the highest aspirations of the moral code ${ }^{31}$ BEDONEBYASYOUDID has a much longer pedigree, being as old as law itself if not older. As the Book of Genesis says: "Whoso sheddeth man's blood, by man shall his blood be shed." 32 Or as the classical Greek dramatist Aeschylus puts it: "The scale of justice falls in equity: the killer shall be killed." ${ }^{33}$

Such sentiments are hardly surprising. Retaliation is a natural expression of anger, ${ }^{34}$ and anger is an entirely predictable reaction to the loss of a loved one, ${ }^{35}$ all the more so when the loss is due to the neglect or default of others. $^{36}$ According to classical Freudian psychoanalytical theory, this angry reaction of an injured person can be "purged" by the venting of hostile feelings on the person responsible, ${ }^{37}$ if not by the victim himself, ${ }^{38}$ then by others. $^{39}$ At the same time, there is the need of the bereaved person to find meaning and order in the universe, in order that the death of a loved one may not be perceived as wholly without purpose. ${ }^{40}$ Finding someone to blame for

31 Matthew 7.12.

32 Genesis 9.6.

33 Agamemnon 250 (translation by Philip Vellacott). The Agamemnon, together with the rest of the Oresteian trilogy, is itself a fascinating study of the relationship between law and vengeance.

34 According to Aristotle anger is the impulse "to conspicuous revenge for a conspicuous slight": Rhetoric 1380b 20. The relationship between anger and retaliation is discussed more fully by James R Averil in Anger and Aggression (1982) at $\mathrm{p} 79$ et seq.

35 Colin Parkes, Bereavement (1972), ch 6.

36 According to Edwin S Schneidman, sometime Professor of Thanatology at UCLA: "It is obvious that some deaths are more stigmatizing or traumatic than others: death by murder, by the negligence of oneself or another person, or by suicide. Survivor-victims of such deaths are invaded by an unhealthy complex of disturbing emotions: shame, guilt, hatred, perplexity. They are obsessed with thoughts about the death, seeking reasons, casting blame, and often punishing themselves." (Deaths of Man (1973))

37 In the same way, we all like to see the "baddie" get his "come-uppance" at the end of the story; if this does not happen, we feel cheated in some way.

38 Breuer and Freud, Studies in Hysteria (1961) at p 5.

39 See Feshbach, Journal of Abnormal and Social Psychology 63 (1961), p 381. For a general discussion of catharsis see Quanty in Perspectives on Aggression (Geen and O'Neal, eds: 1976).

40 In the words of Robert J Kastenbaum: "Things do not just happen; they happen for a reason." (Death, Society and Human Experience (1977), at p 111) 
the death is an obvious way of explaining it. ${ }^{41}$ Thus the imposition of criminal sanctions against those responsible for causing death can serve two purposes: it can make sense of the death in the way just described, and it can provide some measure of catharsis for the bereaved.

In many primitive societies these functions are discharged by the "blood feud", whereby the relatives of the dead person are entitled, even obliged, to levy vengeance on the person responsible for the death or on his family. ${ }^{42}$ Later on in many societies ${ }^{43}$ this often develops into a system of voluntary settlement, whereby the culprit pays a sum of money or compensation in other kind to the aggrieved relatives. ${ }^{44}$ Ultimately this system of informal reparation may develop in turn into one in which the compensation for causing death is fixed by the law. ${ }^{45}$ Though this may vary according to the degree of culpability with which the death was caused, ${ }^{46}$ the measure is often based on the rank of the deceased or his relationship to the aggrieved relative. ${ }^{47}$ Though special provisions may exist for accidental or excusable homicides, ${ }^{48}$ the presumption is that reparation is payable unless there is good reason to the contrary. The point to note here is that sanctions are triggered not by abstract principles of fault or mens rea but by the simple fact that the culprit has brought about a death.

41 Parkes, loc cit at n 35, quotes a widow as saying "I wish there was something I could blame". He observes that the feeling seems to be that, if the person responsible could be found, the loss could be prevented or even undone.

42 William Seagle describes the blood feud as "the matrix of all law": see The Quest for Law (1941), at p 36. For discussion of the blood feud generally see Seagle, $o p$ cit, ch III; Kocourek and Wigmore, Primitive and Ancient Legal Institutions (1915), ch IV; Diamond, Primitive Law Past and Present (1971) p 222 et seq. See also Pollock and Maitland, The History of English Law (2 ${ }^{\text {nd }}$ ed, 1968), vol 2 at $\mathrm{p}$ 449; McAuley and McCutcheon, Criminal Liability (2000), pp 1-2.

43 Thus according to Diamond, loc cit, in the Trobriand Islands lugwa (the blood feud) is seldom carried out, and acceptance of the lula (the peace-making price) is traditional. Compare the Roman Law of the Twelve Tables, which provided for retaliation in cases of maiming (membrum ruptum) but only if there was no settlement (" $n i$ cum eo pacit"): Gaius Institutes III.223; Jolowicz, Historical Introduction to Roman Law (1939), p 174. See generally Kocourek and Wigmore, op cit, p 134 et seq. In Book IX of the Iliad the hero Ajax alludes to such a custom; see also Tacitus, Germania 21.

44 But not all societies mitigate the blood feud in this way; sometimes a formal duel is substituted: Seagle, op cit at n 42, p 39. See also the provision of "cities of refuge" for unintentional killers in the Law of Moses: Deuteronomy 19.1-10.

45 In Anglo-Saxon law this was called wergild, in early Scots law cro, in Brehon law lóg n-enech and in Welsh tribal law galanas: see Essays in Anglo-Saxon Law (1876) at p 279 et seq; Kelly, A Guide to Early Irish Law (1988), p 125 et seq; Ellis, Welsh Tribal Law and Custom (1982), vol II at p 98 et seq; Wormald, Past and Present 87 (1980) at $\mathrm{p} 62$. Compare Kocourek and Wigmore, op cit at $\mathrm{n} 42, \mathrm{p}$ 123 et seq; Seagle, op cit at n 42, ch III.

46 This is the position in Islamic law: see Schacht, Introduction to Islamic Law (1964), p 181 et seq.

47 Thus in Brehon law a man would receive full payment for a dead parent, half payment for an uncle or aunt, one third for a cousin \&c: Kelly, op cit at $\mathrm{n} 45, \mathrm{p}$ 126. In the same way the "honour price" would vary according to the rank of the deceased. Compare Essays in Anglo Saxon Law, above at n 45, pp 279-280.

48 Ellis, op cit at n 45, pp 92-97. 
This preoccupation with responsibility for the death of a human being can also be seen in relation to the punishment of animals for homicide, a not uncommon feature of primitive legal systems. ${ }^{49}$ Commenting on this practice, ${ }^{50}$ Nicholas Humphrey contends that the punishment (as opposed to the extermination on the grounds of safety) of an animal that has caused death can serve no conceivable utilitarian purpose; rather, he suggests, there is a search for culpability so as to "impose order on a world of accidents" 51 and, more specifically, "to make sense of seemingly inexplicable events by redefining them as crimes". ${ }^{2}$ This applies with even more force when sanctions are imposed on an inanimate object, such as a knife or a falling brick. ${ }^{53}$

All of this may seem to be a far cry from the modern penal system, with its sophisticated notions of culpability. Indeed, the history of the common law in this area shows a movement away from objective harm to subjective culpability as the trigger for the imposition of criminal sanctions. ${ }^{54}$ Classical theorists such as Ashworth would like to see this process carried to its logical conclusion, with objective harm removed altogether from the criteria of criminal responsibility. ${ }^{55}$ While this is an entirely understandable goal in rational terms, one suspects in the light of the foregoing discussion that it would not work. As we have seen, there is, at least in cases of homicide, a strong psychological and emotional attachment to harm as a determinant of liability, and it is difficult to see how a workable penal system could ignore this altogether. While nobody in their right mind would suggest a return to the days of the blood feud, it seems that there needs to be some way of coming to terms with the instinct for retaliation without departing further than is necessary from the values of a rational penal system. Some of the philosophical issues to which this gives rise will be considered below, but first of all we need to consider some of the practical problems posed by the instinct for retaliation and by the role of harm in the penal system generally.

First of all, there is the question of murder. This is marked out throughout the British Isles as being the gravest of offences, excepting only treason, and it carries a mandatory sentence of life imprisonment. ${ }^{56}$ This is open to criticism on two grounds. The first of these relates to the mens rea or fault element. At present murder is committed not only by the person who kills intending to kill, but by several other categories of offender, including: (1) the person who intends to cause grievous bodily harm; ${ }^{57}$ (2) the person who

49 See Evans, The Criminal Prosecution and Capital Punishment of Animals (1906)

50 Op cit, foreword to 1988 reprint.

51 Op cit at $\mathrm{p}$ xxiv; and compare the comment quoted above at $\mathrm{n} 41$.

52 Ibid (emphasis in original).

53 As with the deodand, which survived in English law until 1862.

54 See McAuley and McCutcheon, op cit at $\mathrm{n} 42$, ch 1.

55 See Ashworth in Essays in Honour of J C Smith (1987), p 7. For the opposing view see Seney, (1971) 17 Wayne Law Review 1095, (1972) 18 Wayne Law Review 569; Robinson, (1975) UCLA Law Review 266.

56 Criminal Justice Act 1964, s 1 (Republic of Ireland); Murder (Abolition of Death Penalty) Act 1965, s 1 (England and Wales and Scotland); Northern Ireland (Emergency Provisions) Act 1973, s 1 (Northern Ireland).

57 It makes no difference that the defendant did not intend any risk to life; see Cunningham [1982] AC 566. For the Republic of Ireland see Criminal Justice Act 1964, s4. 
without directly intending to kill, is brought within the ambit of murder by the doctrine of "oblique intent" in England and Wales and in both jurisdictions of Ireland, ${ }^{58}$ and by the doctrine of "wicked recklessness" in Scotland, ${ }^{59}$ and (3) the person who, contemplating that another may kill, is party to that enterprise under the law relating to accomplices. ${ }^{60}$ Yet the person whose actions do not result in death will, though equally culpable, be liable at best for attempted murder or wounding with intent, neither of which carry the mandatory penalty. This anomaly of "moral chance" 61 is particularly marked in the case of attempted murder which, as has been pointed out several times in the House of Lords, ${ }^{62}$ requires a greater degree of culpability to be proved than murder itself. ${ }^{63}$ Why should the mere chance factor of whether the defendant caused death have such an impact on criminal liability? Why should a person who intends only to cause grievous bodily harm, but ends up killing his victim, be more severely dealt with than one who fully intended to kill but because of a fluke was unsuccessful? Given that it has been said that no offence varies in culpability as much as does murder, ${ }^{64}$ why should this be the offence with the least degree of sentencing flexibility? On any rational basis the law is ripe for reform here. Yet nothing ever seems to come of the proposals put forward. ${ }^{65}$ Is this because of the ancient tradition set out above, whereby the taking of human life is regarded as a uniquely serious matter, to be marked by condign punishment irrespective of the extent to which the killer was at fault?

The offence of manslaughter presents an equally illogical position to the rational mind. At present it is manslaughter to bring about death by any unlawful and dangerous act ${ }^{66}$ or by any act or omission, lawful or not, done

58 Criminal Justice Act 1964, s 4 (Republic of Ireland); Criminal Justice Act 1967, s 8 (England and Wales); Criminal Justice (NI) 1966, s 4 (Northern Ireland); and see generally Woollin [1999] AC 82.

59 Cawthorne v H M Advocate 1968 JC 32.

60 Accessories and Abettors Act 1861, s 8.

61 See the essay by Ashworth in Eekelaar and Bell (eds), Oxford Essays in Jurisprudence, $3^{\text {rd }}$ series (1987), p 1; Sverdlick, American Philosophical Quarterly 25 (1988) p 79.

62 See Cunningham [1982] AC 566 at 582-583 (Lord Edmund-Davies); Howe [1987] AC 417 at 445 (Lord Griffiths); Gotts [1992] AC 414 at 425-426 (Lord Jauncey).

63 Though not in Scotland, where the mens rea of attempt is the same as that required for the main offence: Cawthorne v HM Advocate 1968 JC 32.

64 This point was made by the Royal Commission on Capital Punishment (1953) Cmd 8932 at para 21. Though the scope of murder is somewhat narrower now than it was then, the comment still holds force.

65 There have been several proposals for the reform of the law of murder in the last forty years, none of which have come to anything: see The Law Commission, Imputed Criminal Intent (1967) Law Com No 10; Criminal Law Revision Committee Fourteenth Report (1980) Cmnd 7844; Law Commission Report No 177 (A Criminal Code for England and Wales) (1989); Select Committee of the House of Lords on Murder and Life Imprisonment (1989, HL Paper 781).

66 England and Wales, and both jurisdictions in Ireland, still retain the doctrine of "constructive" manslaughter, whereby it is manslaughter to cause death by an unlawful act that is likely to cause harm: see DPP v Newbury and Jones [1977] AC 500 (England and Wales, Northern Ireland); People $(A-G)$ v Crosbie and Meehan [1966] IR 95 (Republic of Ireland). In Scotland a similar rule results 
with gross negligence or recklessness. ${ }^{67}$ Why should what would have been a petty assault punishable by a fine or at most a short prison sentence be turned by the fortuitous death of the victim, a death which the defendant may not have foreseen ${ }^{68}$ or even been expected to foresee, ${ }^{69}$ into a serious crime carrying a sentence up to life imprisonment ${ }^{70}$ Why should it be a crime to cause death by grossly negligent conduct but no crime to cause lesser injury by the very same conduct? ?1 A purely rational system of criminal law would not tolerate these anomalies, but much of the pressure for reform of the law of manslaughter seems to be for expansion rather than contraction. ${ }^{72}$ Is this again because of the historic perception of death as something for which special provision must be made ${ }^{73}$

Leaving aside the question of homicide, further questions are raised relating to the place of the victim within the penal system. ${ }^{74}$ It is now generally accepted that victims of crime have the right to expect a certain degree of support from the penal system: in particular, there should be a sympathetic approach to the victim by agencies of law enforcement during the

from the doctrine of culpable homicide by assault: HM Advocate v Rutherford 1947 JC 1; Bird v HM Advocate 1936 JC 19.

67 Adomako [1995] 1 AC 171 (England and Wales, Northern Ireland); People (A-G) v Dunleavy [1948] IR 95 (Republic of Ireland); Paton v HM Advocate 1936 JC 19 (Scotland).

68 The defendant need not foresee the risk even of harm occurring, still less death: see DPP v Newbury and Jones [1977] AC 500 (England and Wales, Northern Ireland); People (A-G) v Crosbie and Meehan [1966] IR 490 (Republic of Ireland); HM Advocate v Rutherford 1947 JC 1 (Scotland).

69 According to Church [1966] 1 QB 59 at 70 the test is whether "all sober and reasonable people would inevitably recognise ... the risk of some harm resulting ... albeit not serious harm".

70 For the approach of the courts to sentencing in cases of involuntary manslaughter see Sweet and Maxwell's Current Sentencing Practice, Part B1-3

71 In England and Wales and in Northern Ireland manslaughter can be committed by "gross negligence", which does not require any foresight of harm: Adomako [1995] 1 AC 171. Non-fatal offences against the person require "Cunningham recklessness", viz that the accused either intended to cause harm or saw the risk of harm occurring and none the less went on to take it: Spratt [1990] 1 WLR 1073.

72 Under clause 54 of the Draft Criminal Code of 1989 (above, n 65) manslaughter would require an intention to cause serious personal harm or recklessness - in the Cunningham sense - as to the causing of such harm. But many of the commentators on corporate manslaughter have argued that the present fault requirements are too stringent; see Wells (1989) 139 NLJ 931; Burles (1991) 141 NLJ 609; Bergman (1991) 141 NLJ 1381. See now the recommendations put forward by the Law Commission in Consultation Paper No 135 Involuntary Manslaughter (1994): McColgan, [1994] Crim LR 547.

73 Careless driving causes similar problems. There is no general crime of causing death by careless driving, and until recently in sentencing for careless driving the courts could not take into account the fact that a death had resulted: see Krawec (1984) 6 Cr App R (S) 366; MacCaig (1986) 8 Cr App R (S) 77; Megaw [1992] 7 BNIL 68. The position has now changed as a result of Simmonds [1999] 2 Cr App R 18. Under article 14 of the Road Traffic (NI) Order 1995 it is an offence to cause death or serious bodily injury by careless driving whilst under the influence of drink or drugs; compare Road Traffic Act 1988, s 3A.

74 See Shapland, Wilmore and Duff, Victims in the Criminal Justice System (1985); Miers, (1992) 55 MLR 482; Grohovsky, (2000) 64 J Crim L 416. 
investigative process and during the trial $;{ }^{75}$ he should be kept informed of what is going on $;^{76}$ the court should be alert to the possibilities of mediation and of reparation. ${ }^{77}$ It is when one passes beyond this that more controversial issues arise. Should the victim, for instance, have the right to decide whether a prosecution should be brought? ${ }^{78}$ Should he be able to insist on a prosecution even where the authorities refuse to press charges? ${ }^{79}$ Should his views be taken into account at the sentencing stage? ${ }^{80}$ Should he have the right to legal representation in sentencing proceedings, and should he be able to address the court? ${ }^{81}$ Should he be able to appeal against a sentence that he perceives to be too lenient ${ }^{82}$ It must be stressed, of course, that not all victims will necessarily want revenge; ${ }^{83}$ even if they do, those who express such views to the media might not necessarily be prepared to do so in the formality of the courtroom and in the presence of the accused. Nevertheless, in so far as there is a risk of vindictiveness in this context, ${ }^{84}$ is this something with which the law must come to terms?

A related but rather different issue is the extent to which the feelings of the wider public should be taken into account. This was a problem that arose in the James Bulger case, where the Home Secretary set a higher tariff for the two young killers Venables and Thompson than the one recommended by the trial judge. This was partly in response to a public campaign mounted by the Sun and other tabloid newspapers ${ }^{85}$ and it was held by the House of Lords that the Home Secretary had erred by taking irrelevant considerations into account. ${ }^{86}$ However, differing opinions were expressed in the case as to the part public opinion should play in matters of this sort. In this context Lord Goff and Lord Steyn both drew a distinction between public concern of a general nature with regard to the punishment of certain types of offence on the one hand, and public clamour that a particular individual in a particular case should be singled out for severe punishment, ${ }^{87}$ saying that it was

75 See the Victim's Charter (1996).

76 Miers, op cit at n 74, p 497.

77 Ibid, pp 497- 498.

78 Ibid, pp 499-501; and see $R$ v DPP ex parte Manning [2000] 3 WLR 463; In re Adams' Application [2001] 3 BNIL 1; Burton, [2001] Crim LR 374

79 In England and Wales he can in such cases bring a private prosecution, as was done in the case of the Stephen Lawrence murder.

80 Miers, op cit at n 74, pp 501-503; Rubel, (1985-86) 28 Crim LQ 226; Whitrod, (1986) 10 Crim LJ 76.

81 Miers, op cit at n 74, p 502.

82 As we have seen, section 36 of the Criminal Justice Act 1988 allows for such an appeal in England and Wales and in Northern Ireland, but it requires a reference by the Attorney-General.

83 According to Miers, op cit at n 74, p 502, victims of crime who support "tough" sentences in the abstract may often choose a sentence in line with the ordinary tariff for their "own" offender.

84 See Grohovsky, op cit at n 78, p 429.

85 This included a petition signed by over a quarter of a million people urging the Home Secretary to keep Venables and Thompson in jail for life: see the note by the present author at (1999) 50 NILQ 204.

${ }^{86} R \mathrm{v}$ Secretary of State for the Home Department, ex parte Venables: $R \mathrm{v}$ Same, ex parte Thompson [1998] AC 407: see note at (1999) 50 NILQ 204.

87 See $R$ v Secretary of State for the Home Department, ex parte Doody [1993] QB 157 at 197 (Staughton LJ) 
legitimate for a sentencing authority to take the former concern into account but not the latter. ${ }^{88}$ In a similar vein Lord Hope said that considerations of this sort were irrelevant to the judicial exercise, and should not have been taken into account. ${ }^{89}$ Lord Lloyd, on the other hand, doubted whether the distinction drawn by Lord Goff and Lord Steyn was a workable one, saying that in this context the representations taken into account by the Home Secretary might be criticised as illogical, prejudicial and ill-informed, but they nevertheless served to indicate a level of general public concern to which he was entitled to have regard in upholding public confidence in the criminal justice system. ${ }^{90}$ Lord Browne-Wilkinson expressed no concluded view on the matter, but said that the courts should be slow to impose judicial constraints on what was essentially an executive function. ${ }^{91}$ This suggests that he would have been reluctant to allow public outrage of this sort to have an influence on the passing of a sentence by a judge. All of this leaves the courts in a very difficult position in cases involving a high degree of public outrage. If they take the outrage into account, they are guilty, in the words of Lord Steyn, of an "abdication of the rule of law". ${ }^{22}$ If they do not, they will immediately become targets of hostile criticism in the press and elsewhere, and may find their sentences increased on appeal as unduly lenient. ${ }^{93}$ The law cannot have it both ways. There is clearly a need for the courts to rethink the ways in which public outrage and the instinct for retaliation operate within the criminal process. In the remainder of this paper we shall examine the philosophical framework within which this might be done, and look at where it leads us.

\section{The Philosophy Of Retaliation}

According to Stephen, "the criminal law stands to the passion of revenge in much the same relation as marriage to the sexual appetite". ${ }^{94}$ Yet it hardly needs to be said that the idea of punishing someone simply because of the harm he has done does not fit in at all well with the traditional justifications of punishment. It does not fit in with the classical utilitarian notions of prevention, deterrence and rehabilitation, ${ }^{95}$ inasmuch as these look forward to the future well being of society, whereas retaliation looks back to the harm done. It does not even fit in with retribution, ${ }^{96}$ for retribution is based on

88 [1998] AC 407 at 491 (Lord Goff), and 525 (Lord Steyn)

89 Ibid at 537.

90 Ibid at 516.

91 Ibid at 503 .

92 Ibid at 526.

93 As in the case of Susan Christie, above at nn 14-17.

94 General View of the Criminal Law of England, p 99.

95 These theories go back to Plato and Aristotle, but their fons et origo in modern penal theory is Beccaria's famous essay of 1764, "On Crimes and Punishment". See also Fitzgerald, Criminal Law and Punishment (1961), pp 206-216; Gross and von Hirsch, Sentencing (1981), part III; Page, The Sentence of the Court (1948), p 44.

96 Some writers, it is true, treat retribution and retaliation as interchangeable concepts: see Page, op cit, pp 39-41. But the essential difference is highlighted by Hart, who defines retribution as "the application of the pains of punishment to an offender who is morally guilty": Punishment and Responsibility (1968), p 9. Retaliation, as we have seen, does not imply moral guilt. 
fault and desert, whereas retaliation as we have seen is concerned less with subjective fault than with objective harm. ${ }^{97}$

Efforts are sometimes made to justify retaliation as bringing about the restoration of a "moral balance" which has been disturbed by the original harm. ${ }^{98}$ Thus according to Kant "retaliation (jus talionis) . . . is the only principle which . . . can definitely assign both the quantity and the quality of a just penalty". ${ }^{99}$ In the same way Hegel declares that "wrong negatives rights, but punishment negates the negation". ${ }^{100}$ However, such metaphysical arguments will have little appeal to those who argue that punishment may involve the infliction of pain not only on the offender but also on his family, to say nothing of the cost in some cases to the State. It should therefore surely only be imposed where some benefit can be shown to accrue from it. Besides which, theories of "moral balance" carry the implicit assumption that two wrongs make a right. This is a doubtful notion to apply to punishment even in cases of retribution, where the offender has been shown to be at fault in some way. To use such a theory to justify retaliation for the doing of harm irrespective of fault is totally indefensible. ${ }^{101}$

Another theory sees the punishment of harm in terms of a denunciation by society of the wrong done coupled with a proclamation to the world at large that such conduct will not be tolerated. ${ }^{102}$ This sort of theory is especially relevant to the sentiment of public outrage, and is exemplified by Stephen's famous assertion that "it is highly desirable that criminals should be hated, and that the punishment should be so contrived as to give expression to that hatred, and to justify it . . . by gratifying a natural healthy sentiment". ${ }^{103}$ Coupled with this is the idea of society being able, as it were, to "get things off its chest" by expressing its repugnance towards anti-social conduct. ${ }^{104}$ However, though this theory of punishment as denunciation is more intellectually satisfying than a metaphysical theory of "moral balance", it is still open to objection in the present context on the ground that the mere doing of harm, independently of considerations of fault, is not something which would obviously seem to merit denunciation by society. There are also four more general objections that can be raised to the theory. Firstly, as Page argues, ${ }^{105}$ the postulated resentment or hatred of society for the evildoer is - one might add even in cases of homicide - often something of an artificial construct; it is not always the most deserving criminals who attract

97 Ibid: Fitzgerald, op cit at n 95, p 203; Gross and von Hirsch, op cit at n 95, part IV.

98 Fitzgerald, op cit at n 95, pp 203-204.

99 Philosophy of Law (translation by W Hastie, 1887), p 196. See also Kleinig, Punishment and Desert (1973), p 121.

100 Philosophy of Rights, para 101, quoted by Page, op cit at n 95, p 38.

101 Reparation - the "undoing" of the harm by the offender, for instance by way of compensation - is a totally different matter.

102 Page, op cit at n 95, p 40.

103 History of the Criminal Law in England, Vol II, p 81; compare Feinberg in Gross and von Hirsch, op cit at n 95, pp 23-36.

104 Thus Adam Smith, in his Theory of the Moral Sentiments, declared that retributive punishment was justified since it satisfied man's natural resentment against those who do evil: Page, op cit at n 95, p 40. In so far as such resentment arises from harm-doing irrespective of fault, retaliatory punishment has the same effect.

105 Op cit, pp 41-42. 
the most hatred. ${ }^{106}$ Secondly, where such emotions do exist they may be affected as much by prejudice as by desert. ${ }^{107}$ Thirdly, public outrage may reflect not so much the reactions of "society" as those of the victims of the crime or even of the editors of tabloid newspapers and others who are in a position to influence and to manipulate public opinion. ${ }^{108}$ Last but not least, even granted that the emotion of outrage may be justified in the particular case, where is the benefit to society in its being "communicated", especially where this involves the deliberate infliction of suffering on the recipient?

So far we have seen that neither the theory of moral balance nor the theory of punishment as denunciation really provide a satisfactory way of locating the retaliatiory instinct within the bounds of a rational philosophy of punishment. A rather different angle on the matter is provided by Lacey, ${ }^{109}$ who approaches the problem from the other end, as it were, by questioning the extent to which our philosophy of punishment should be wedded to purely rational considerations. For Lacey, the traditional theories of punishment are to be located within the matrix of classical liberal thought, a distinctive feature of which is its vision of humankind as essentially rational beings, capable of reasoning about the best means to chosen ends, and able at least to govern their emotions both in engaging the process of reasoning and in acting upon its outcome. Thus in the liberal view of morality, reason is privileged over emotion, and the role of intuition tends to be played down, rationalised or excused. ${ }^{110}$ This view is all very well as far as it goes, but Lacey accuses it of producing a rather naïve view of human nature, which in turn has several very important and adverse effects on liberal thought and action. ${ }^{111}$ In this context she criticises the traditional view of human beings reacting in a calculated and rational way to the threat of punishment, in a passage which in the present context deserves to be quoted at length.

"The most obvious difficulty which this feature presents in the context of criminal justice, as elsewhere, is what might be called the argument from real life: despite the fact that few would deny any moral relevance to the ideas of planning and decision, in the sense of our own relative power and freedom, it simply is not the case that people behave in the totally rational way this assumption suggests. Human motivation, as one would expect, is far more complex than the liberal vision would indicate. This point is of wider importance than just to the issue of how citizens react to the threat of punishment; it bears on the general significance we attach to the institution of punishment, which seems to be far greater than would be justified merely by a calculation of its direct and indirect contribution to the prevention of offences or the mitigation of their seriousness. ... [I]t seems clear ... that an appreciation

106 It has been argued, for instance, that the killers of James Bulger would have attracted less public hatred had they been adults; the fact that they themselves were only children made the crime more horrific.

107 Kleinig, op cit at n 99, p 125

108 See above at $\mathrm{n} 85$.

109 State Punishment (1988).

110 Op cit, pp 145-146.

111 Op cit, p 166. 
of the emotive and symbolic aspects of human attitudes to practices such as punishment and the threat of punishment must form an important part of the informational basis from which our reading of the traditional theories and our own normative thought about that practice should proceed." 112

How then are the functions of punishment to be defined? In approaching this question, Lacey locates her discussion within the context of what she calls the "community conception" of criminal justice, ${ }^{113}$ which recognises humankind as "essentially, necessarily and primarily social beings". ${ }^{114}$ Within this context it is possible to reconstruct many of the traditional justifications of punishment, such as retribution and the prevention of harm to society. Most significantly from our point of view, punishment can, according to Lacey, be seen to address two important social needs. The first of these is the need to forestall, or at least to minimise, any resort to private vengeance or self-help, which might cause disproportionate suffering and involve excessive costs, whilst undermining the stability of and respect for the community's legal system as a whole. Secondly, there is the need to appease and satisfy what Lacey terms the "grievance-desires" of victims, not only so as to reduce their suffering and to forestall self-help, but also to demonstrate that the community takes seriously the harm done to the victim and takes upon itself the responsibility for upholding the standards breached, which it hopes to vindicate through the process of conviction and punishment. ${ }^{115}$

As we have seen, these two functions - the forestalling of private vengeance and the appeasing of the grievance-desires of victims - have historically played a major role in the development of the criminal process. If they can still be regarded as legitimate justifications of state punishment, then we do have a basis upon which the penal system can accommodate the notion of retaliation. This is so even if the impulse to vengeance and the grievance desires of victims are themselves not always wholly rational. We are human beings, not calculating machines, and it can be argued that the penal system of a society must, if it is to be effective, reflect the attitudes and preoccupations of that society.

However, there must be a degree of caution here. As Lacey herself points out, if a community is to be true to its own essential values, a balance must be struck between the welfare and autonomy of victims and potential victims and that of offenders and potential offenders. ${ }^{116}$ In particular, no punishment should be so severe as to reflect a complete absence of respect for or denial of the offender's autonomy, ${ }^{117}$ and the commission of an offence should not deprive offenders of their civil rights. ${ }^{118}$ Furthermore, as we have seen, ${ }^{119}$ retaliation instincts and grievance-desires may themselves be constructed

112 Loc cit.

113 Op cit, p 169.

114 Op cit, $\mathrm{p} 171$.

115 Op cit, p 184.

116 Op cit, p 195

117 Ibid. Lacey calls this the principle of "residual autonomy".

118 Ibid. Lacey calls this the principle of "humane economy".

119 Above at n 108. 
notions, or may at least be susceptible of exaggeration in particular social contexts. There are also certain emotional and non-rational factors which should have no place in any civilised penal system, such as race prejudice, sectarian bigotry or mob hysteria. ${ }^{120}$ Whilst we may be allowed to proceed some way down the path of allowing the penal process to take account of outrage and the instinct for retaliation, we cannot go too far. So what are the principles on which we should proceed? This is a question to which we must now turn.

\section{The Way Forward?}

It is one thing for us to concede that the criminal process must accommodate itself in some way to the retaliatory instinct. It is quite another thing to say that retaliation should still be accepted as a worthwhile end in itself. If retaliation is to play any part at all in the modern criminal process, it can only be, as it were, as a concession to human frailty. The purpose of this concession is, in the terms used by Lacey, to assuage the grievance-desires of victims and to forestall resort to private vengeance. These are, unlike retaliation itself, essentially utilitarian or consequentialist goals. So what weight should the criminal process give to these goals? In particular, to what extent should they be allowed to justify punishing an offender more severely than he would otherwise deserve? This is a problem common to all the utilitarian rationales of punishment, and it can be resolved in a number of ways, as we can see by looking at how some of these rationales are accommodated within the current Northern Ireland sentencing system.

In some cases, utilitarian considerations may be allowed to override just desert altogether. This is precisely what can happen in the case of incapacitation for dangerous offenders. ${ }^{121}$ In Northern Ireland, a custodial sentence can be imposed not only where the offence committed is serious enough to justify it, ${ }^{122}$ but also, in the case of a violent or sexual offence, where such a sentence is needed to protect the public from serious harm. ${ }^{123}$ Moreover, the courts may in the latter case sentence the offender to any term up to the maximum allowed for the offence, so long as they conclude that

120 The historic attitude of juries in the Southern United States to black defendants accused of the rape of white women is a classic example of this: see Quentin Reynolds' account of the famous Scottsboro trial in Courtroom (1950), chapters $\mathrm{X}$ and $\mathrm{XI}$.

121 This is even more so in England, where section 2 of the Crime (Sentences) Act 1997 introduced mandatory life sentences for repeat serious offenders: see now section 109 of the Powers of Criminal Courts (Sentencing) Act 2000. For a discussion of the rationale behind these provisions see the White Paper, Protecting the Public (Cm 3190) and the remarks of Lord Bingham CJ in Kelly [1999] 2 Cr App R (S) 176 at 182.

122 "... [A] court shall not pass a custodial sentence on the offender unless it is of the opinion...that the offence, or the combination of the offence and one or more offences associated with it, was so serious that only such a sentence can be justified for the offence . . . ": Criminal Justice (NI) Order 1996 ("CJO"), art 9(2)(a); compare the Powers of Criminal Courts (Sentencing) Act 2000 ("PCCSA"), s 79(2)(a).

123 ". . . or . . . where the offence is a violent or sexual offence, that only such a sentence would be adequate to protect the public from serious harm from him": CJO, art. 9(2)(b); compare PCCSA, s. 79(2)(b). 
this is necessary for the protection of the public. ${ }^{124}$ This can lead to the passing of sentences considerably in excess of what would be justified by strict considerations of desert. ${ }^{125}$ Though it has been said that in passing sentence under these provisions the courts must balance the need to protect the public with the need to ensure that the sentence is not out of all proportion to the nature of the offending, ${ }^{126}$ it is clear that this must refer to the harm done rather than to the culpability of the offender; where the offence is one involving serious harm, and the offender is likely to cause such harm in the future, questions of subjective culpability will take a back seat. ${ }^{127}$ Because of this we can term incapacitation a "strong" utilitarian rationale when set against considerations of just desert within the Northern Ireland sentencing system.

In other cases, utilitarian considerations give way to just desert. Rehabilitation is an example of this. Thus a custodial sentence can never be passed on rehabilitative grounds, but only (leaving aside the case of a preventive sentence for a violent or sexual offence) where the offence committed is so serious that only such a sentence can be justified for the offence. ${ }^{128}$ Similarly, the length of a custodial sentence must always be (again leaving aside the preventive sentence) commensurate with the seriousness of the offence; ${ }^{129}$ there can be no question of keeping an offender in prison for a longer period in his own interests. ${ }^{130}$ One might expect to see a different picture when it comes to community sentences such as probation, but even here just desert reigns supreme; such a sentence may not be passed unless the court is of the opinion that the offence committed is serious enough to warrant such a sentence, ${ }^{131}$ and any restrictions on liberty imposed

124 "The custodial sentence shall be . . . where the offence is a violent or sexual offence, for such longer term (not exceeding [the] maximum) as in the opinion of the court is necessary to protect the public from serious harm from the offender": CJO, art 20(2)(b); compare PCCSA, s 80(2)(b).

125 Thus, for instance, long sentences may be imposed for what are in themselves relatively trivial cases of indecent assault: see Bowler (1994) 15 Cr App R (S) 78 (six years); Webb [1996] 1 Cr App R (S) 352 (six years); Langton [1998] 1 Cr App R (S) 217 (four years).

126 Mansell (1994) 15 Cr App R (S) 771; Crow and Pennington (1995) 16 Cr App R (S) 409 .

127 Thus compulsive offenders may be sentenced to life imprisonment in appropriate cases: see Scott (1981) 3 Cr App R (S) (arson); Williams (1986) 8 Cr App R (S) 480 (rape); Hatch [1997] 1 Cr App R (S) 22 (buggery); Ellis [1999] 1 Cr App R (S) 245 (kidnapping).

128 “. . . [A] court shall not pass a custodial sentence on the offender unless it is of the opinion . . . that the offence, or the combination of the offence and one or more offences associated with it, was so serious that only such a sentence can be justified for the offence ...": CJO, art 9(2)(a); compare PCCSA, s 79(2)(a).

129 "The custodial sentence shall be . . . for such term (not exceeding the permitted maximum) as in the opinion of the court is commensurate with the seriousness of the offence, or the combination of the offence and one or more offences associated with it ...": CJO, art 20(2)(a); compare PCCSA, s 80(2)(a).

130 This was probably not permissible even under the old law: see Winchester [1978] 9 NIJB; Roote (1980) 2 Cr App R (S) 368.

131 "A court shall not pass on an offender a community sentence unless it is of the opinion that the offence, or the combination of the offence and one or more 
by such a sentence must equally be measured, at least in part, by reference to the desert of the offender. ${ }^{132}$ All in all, while rehabilitation may play an important part in influencing the courts' choice of sentence within the parameters of just desert, it cannot, unlike incapacitation, override just desert altogether. We can therefore term it a "weak" utilitarian rationale when set against just desert within the Northern Ireland sentencing system.

A more even balance between utilitarian and desert considerations is to be found in relation to deterrence. Judges have a long tradition of imposing long sentences on offenders on the basis that they are needed to deter the offender and others from committing similar offences in the future, and in Cunningham ${ }^{133}$ the question arose whether this practice was still possible under the new legislation with its criterion of offence seriousness and just desert. The appellant was sentenced to four years' imprisonment for robbing a shop; the judge remarked that this sort of offence was far too prevalent, and that others who were tempted to commit such offences must realise that a long deterrent sentence would follow. The Court of Appeal upheld the sentence, rejecting the appellant's contention that deterrence could no longer be taken into account. The phrase "commensurate with the seriousness of the offence" was taken to mean "commensurate with the punishment and deterrence which the seriousness of the offence requires". ${ }^{134}$ Whilst the legitimacy of this interpretation is open to doubt, ${ }^{135}$ it is now clear that while it would be illegitimate for a court to sentence an offender grossly in excess of what he deserves in order to deter future criminality, just desert is not, as it is with rehabilitation, the overriding criterion. If incapacitation is a "strong" rationale within the context of the Northern Ireland sentencing system when set against just desert, and rehabilitation a "weak" rationale, deterrence could be termed an "intermediate" rationale, standing somewhere between the two.

This brings us on to the crucial question. If retaliation, or rather assuaging the outrage caused by the retaliatory instinct, is to be a legitimate rationale for the imposition of punishment within the criminal justice system, where should it stand on the scale? Is it to be a "strong" rationale like incapacitation, a "weak" rationale like rehabilitation, or an "intermediate" rationale like deterrence?

If outrage were to be regarded as a "strong" rationale, that would mean that in appropriate cases just desert could be ignored altogether, and an offender sentenced to condign punishment purely to assuage the angry feelings of victims and others. Whilst there are no doubt some who would be glad to

offences associated with it, is serious enough to warrant such a sentence": CJO, art 8(1); compare PCCSA, s 35(1).

132 “. . . [W] Were a court passes a community sentence ... the restrictions on liberty imposed by the order or orders shall be such as are commensurate with the seriousness of the offence, or the combination of the offence and one or more offences associated with it ...”: CJO, art 8(2)(b); compare PCCSA, s 35(3)(b).

133 (1993) 14 Cr App R (S) 444. This was a case decided under section 2(2) of the Criminal Justice Act 1991, the predecessor of the Powers of Criminal Courts (Sentencing) Act 2000.

134 Ibid at 447.

135 See the comments of Ashworth in Sentencing and Criminal Justice ( $2^{\text {nd }}$ ed, 1995), p 83. 
see this happen, ${ }^{136}$ such an approach could have no place in a rational penal system. It is one thing to ignore just desert in the light of the need to protect the public from serious harm. After all, this is a consideration that can justify the indefinite detention of those who have not been convicted at all, as in the case of those suffering from dangerous mental disorder. It is another thing to allow just desert to be overridden altogether in order to assuage outraged feelings. Satisfying the grievance-desires of victims and forestalling private vengeance, worthwhile though these ends may be, cannot be given such great weight. ${ }^{137}$

If it were a "weak" rationale, that would mean that while outrage could be taken account of in appropriate cases, an offender could never be punished in excess of his just desert. The trouble with this is that it does not come anywhere near addressing the problems identified in the first part of this paper. Indeed, given that the retaliatory instinct invariably calls for punishment to be increased rather than diminished, one can see few cases where it would make very much difference if, like rehabilitation, it were to be limited in this way.

This leaves us with the third possibility, the "intermediate" rationale. Like deterrence, the satisfaction of outrage would be something that could be taken into account in imposing punishment, even to the extent of punishing an offender more than he might otherwise strictly deserve. But a balance would have to be maintained;138 in particular, it would not be possible to ignore just desert altogether, as in some cases of incapacitation. This approach gains some support from the case of Cox, ${ }^{139}$ in which the appellant was sentenced to four months' detention in a young offender's institution for reckless driving, the judge observing that "there is great public concern about driving of this sort". ${ }^{140}$ The Court of Appeal held that the prevalence of offences of a particular class and public concern about them were relevant factors to be taken into account in determining the seriousness of the offence committed in any particular case. Though, as with deterrence, the reasoning of this is open to question, it does provide a workable approach to the retaliatory instinct and the problem of outraged feelings. If the courts can take public concern into account, why not also the concerns of victims? If they can take into account concern about the prevalence of the offence, why not concern about the harm it has brought about?

\section{Some Conclusions}

Earlier on in this paper we identified some practical problems posed by the instinct of retaliation in the modern penal process. We cannot provide obvious answers to these problems, but the previous discussion will perhaps help us to point to where the answers might lie.

\footnotetext{
136 For instance, those who wrote to the Home Secretary urging him that the killers of James Bulger should be locked up for life: above, $\mathrm{n} 85$.

137 To do so would be to violate the principles of residual autonomy and of humane economy identified by Lacey: see above at nn 117 and 118 .

138 Lacey, loc cit.

139 (1993) 14 Cr App R (S) 479.

140 Ibid at 481.
} 
The first set of problems relate to the overall structure of criminal liability, and to the extent to which the gravity of offences should be affected by the harm done - in particular, by the causing of death. If we apply the approach suggested above, we have to balance the problem of "moral chance" inherent in punishing an offender on the basis of the harm caused against the need to satisfy the outrage caused by that harm. On this basis, the present law of murder seems to strike an appropriate balance, given that the only case which raises any real problem of moral chance (apart from that of the accomplice, which gives rise to somewhat different considerations ${ }^{141}$ ) is the killer who intended only to do serious harm without endangering life. ${ }^{142}$ While this is a problem, it is surely not a very serious problem. The structure of manslaughter is less satisfactory on this count. Whilst manslaughter by gross negligence seems to strike a reasonable balance between the factors mentioned above, the same cannot be said for constructive manslaughter, given that the only fault element required is that for the unlawful act together with negligence as to some harm occurring as a result. ${ }^{143}$ So our balancing test would suggest altering the fault element here so as to require at least negligence as to the causing of death. On the other hand, the balance in cases of corporate killing would seem to be tipped too far the other way; once again, the Law Commission would seem to have got it more or less right with their test of "gross management failure". ${ }^{144}$ There would also be a case for having an offence of causing death by careless driving, at least where the defendant was negligent as to the causing of death. ${ }^{145}$ On the other hand, there would be less call for an offence or offences of causing non-fatal harm by negligence. While this might be justified on a strictly rational view if we are to have an offence of causing death by negligence, ${ }^{146}$ the problem of outraged feelings is far less apparent in this sort of case, and there is therefore less to balance in the scale against the problem of moral chance.

The other problem relates to the role of public outrage in the sentencing process. Were the House of Lords right in the Bulger case to say that the Secretary of State should have ignored the representations made to him by members of the public demanding a long tariff? ${ }^{147}$ Once again, we need to balance on the one hand the need to satisfy the grievance-desires of the victims and to forestall private vengeance, and on the other the need to ensure that the punishment imposed is not out of all proportion to the desert of the offender. There is no obvious answer to this conundrum, but perhaps

141 Any unfairness here arises from the general law relating to parties to a crime rather than from the substantive law of murder. But even the accomplice must be proved at least to have had murder "within his contemplation": see DPP for NI v Maxwell [1978] NI 42.

142 See Ashworth, Principles of Criminal Law ( $3^{\text {rd }}$ ed, 1999), at p 270.

143 Op cit at 306-309; see the Law Commission Report Legislating the Criminal Code: Involuntary Manslaughter (Law Com No 237 (1996)) at paras 5.14 - 5.16, which recommends the abolition of constructive manslaughter in its present form.

144 Clause 4(1) of the Draft Involuntary Homicide Bill appended to the Law Commission Report cited above; see commentary by Wells at [1996] Crim LR 545.

145 See the case of Stephen Owen, above at nn 18 - 21.

146 See Simester and Sullivan, Criminal Law, Theory and Doctrine (2000), at pp 369-370.

147 See above at nn 85-93. 
there is something to be said for drawing a distinction in this context between outrage on the part of victims and outrage on the part of outsiders. ${ }^{148}$ The grievance-desires of victims are surely more worthy of consideration than those of strangers, and less open to manipulation by the media and others. The risk of private vengeance is also more apparent. To take the opinions of victims into account but not those of others would allow the courts to make allowance for some of the factors we have been considering whilst avoiding the risk of media sentencing and mob hysteria.

One thing is for certain; in an age of mass communication where presentation is more important than substance and the spin-doctor is king, the pressures of public outrage on the courts are likely to increase rather than diminish. One is encouraged to hope that the courts will be able to formulate sound principles for dealing with these pressures, and it is with this in mind that this article is offered as a contribution to the debate.

148 See further the arguments of the present author at (1999) 50 NILQ 204, 209. 